\title{
The Smuts Government's justification of the emergency regulations and the impact thereof on the Ossewa-Brandwag, 1939 to 1945
}

\author{
Anna La Grange ${ }^{1}$ \\ North-West University
}

\begin{abstract}
The Second World War was a dynamic time in the South African past - a time when war was not only fought against foreign enemies but also at home within the Afrikanerdom. The metaphorical battle on the home front had two sides. The one was resistance against the Smuts government's war effort, and the second was the Smuts government's actions to curb internal unrest. The main attempt to dampen the internal unrest manifested itself in the form of various emergency regulations and war measures. These regulations and measures affected the Ossewa-Brandwag, a dualistic organisation within the Afrikanerdom, which would eventually lead the resistance directly against the war effort. This article delves into the Smuts government's justification of the emergency regulations and analyses the impact thereof on the Ossewa-Brandwag.
\end{abstract}

\section{Introduction and contextualisation}

This year, 24 May 2020 marked the $150^{\text {th }}$ anniversary of the birth of Jan Christiaan Smuts. This commemoration provided the ideal opportunity for academics, and especially historians, to reflect on aspects of Smuts's life and political career. One such aspect is Smuts's role in the Second World War. In short, "Smuts had to fight a war not only on the military but also on the home front". ${ }^{2}$ The battle on the home front would manifest itself mainly in the form of Afrikaner resistance to the war effort and, consequently, the introduction of various war measures, including wartime emergency regulations. Blake notes that the Afrikaner resistance to the Smuts government's war effort is not only about "divided loyalties" but also about "betrayal and revenge". 3 Indeed, the division within the Afrikanerdom during the Second World War is, as Blake maintains, "a story that has not yet been fully told". ${ }^{4}$

Anti-war sentiments, closely linked to Afrikaner nationalism, were so commonplace during the Second World War that Grundlingh refers to it as "a corollary of the general thrust of Afrikaner nationalism at the time". ${ }^{5}$ The role Smuts had to play in the Second World War therefore comprised two parts. On one side of the spectrum, he had to manage South Africa's participation in the war, and on the other, he had to ensure that the internal situation in South Africa was controlled so that his position as leader was not undermined. ${ }^{6}$ As Hancock notes, two varying yet related attitudes appear in Smuts's 
writings, "the mood of an observer, trying to understand events in the outer world and their significance for South Africa; the mood of a participant, trying to discover his own duty". ${ }^{7}$ Despite the complicated situation in South Africa, it is clear that Smuts was definitely aware of world events and he did not hold back his opinions. For example, between 1 October 1938 and 23 August 1939, Smuts delivered a total of twenty speeches on international events and their possible effects on South Africa. ${ }^{8}$ Smuts is a complex historical figure on whom much research has already been done and on whom much research can still be done: " $[\mathrm{d}]$ ifferent people looked at Smuts from different angles and different backgrounds. All researchers in due course encounter extreme difficulty in analysing Smuts's complex personality."10

Hans van Rensburg, leader of the Ossewa-Brandwag (OB) (the organisation that would later lead the resistance to the war effort), also had a conflicting opinion about Smuts stating, "in spite of his reputation for coldness of heart, Smuts had a very human side to his nature". ${ }^{11}$ As the leader of South Africa during the Second World War, Smuts undoubtedly had an influence not only on the justification of South African participation in the war, but also on the introduction of various measures to stop domestic unrest. This article, therefore, does not seek to analyse Smuts's personality, but rather to analyse how the Smuts government - and, consequently, Smuts himself - justified the emergency regulations.

As a large part of this article focuses on the OB, it is necessary to give some context regarding the organisation. Established in February 1939, the OB had its beginnings in the Great Trek centenary celebrations of 1938. The organisation rapidly grew and soon turned into a mass movement within the Afrikanerdom. The OB existed for more than a decade, until it was eventually disbanded in 1954. Starting out as a cultural organisation at the start of 1939, the outbreak of the Second World War quickly led to the OB starting to operate within the political sphere, especially by opposing the Smuts government in its war effort. In short, the Second World War would contribute to the OB taking on the role of a dualistic organisation within the Afrikanerdom. ${ }^{12}$ In most instances, the OB even used Afrikaner culture as a political weapon to encourage activism and sabotage against the war effort. These activist actions of the OB largely contributed to the Smuts government's decision to install various war measures and emergency regulations.

A general analysis of the $\mathrm{OB}$ - primarily based on the records in the $\mathrm{OB}$ archive - has been offered by Marx. Marx also succeeded in describing the link between Afrikaner nationalism and the rise of the $\mathrm{OB}$ as a popular Afrikaner organisation. ${ }^{13}$ The internal political situation in South Africa during the Second World War has been examined by Fokkens. ${ }^{14}$ The review by Fokkens focuses mainly on the role of the Union Defence Force (UDF) in the suppression of the unrest, and does not really cover how the government justified the implementation of the various emergency regulations. ${ }^{15}$ Furlong analysed the Second World War situation within South Africa by exploring the OB, anti-British sentiments, the influence of Nazi ideologies and the role of the National Party (NP) during the war. ${ }^{16}$ This article builds on Furlong's writings by discussing how the Smuts government justified the implementation of these regulations and how the emergency regulations affected the OB specifically. This is an important contribution to the historiography of South Africa's political situation during the war, 
and to the historiography of the OB. In order to make a meaningful contribution to the historiography, the purpose of this article is threefold:

- $\quad$ to explore the Smuts government's justification for these war measures, more specifically the emergency regulations;

- $\quad$ to kaleidoscopically discuss the nature and extent of these measures; and

- $\quad$ to examine the outcome of these measures and regulations on OB members.

- Particular attention is paid to the internment policy and the handling of political prisoners and internees by the Smuts government.

\section{The Smuts government's justification of the war measures and emergency regulations}

South Africa's participation in the Second World War, together with the opposition to it and the measures put in place against internal opposition, should be considered in the broader context of the South African population:

The South Africans were not homogenous. They made a distinction between die volk, the white people who constituted a nation, and die bevolking, the total population, most of which did not belong to the nation. ${ }^{17}$

Certain Afrikaners took the distinction even further by seeing only white Afrikaansspeaking individuals (Afrikaners) as part of the volk, and everyone else as only part of the bevolking. ${ }^{18}$ This distinction must be taken into account to understand the broader historical context within South Africa during the Second World War. Furthermore, it is also important to mention that the study reported here focused solely on the white population (the volk) because the war measures mainly affected this group directly.

In September 1939, Smuts won the war debate in Parliament with a difference of only 13 votes. ${ }^{19}$ On 6 September 1939, South Africa officially declared war on Germany under Proclamation 197 of $1939 .{ }^{20}$ This declaration of war had a direct effect on the OB as an Afrikaner movement. ${ }^{21}$ According to Hancock, Smuts was aware of the possible internal opposition to war, and even the possibility of a civil war, "[h]e did not close his eyes to that danger but took precautions against it." ${ }^{22}$ For example, Lieutenant G Diedericks, a police officer, was commissioned to set up a special unit with the main purpose of investigating political crimes. This command was received even before the Second World War officially broke out. ${ }^{23}$ On top of the internal situation, Smuts also had to deal with South Africa's Defence Force, which was by no means ready for warfare. ${ }^{24}$

At the outbreak of war in 1939, the UDF consisted of only 3500 personnel, and some 14000 part-time soldiers belonging to the Active Civilian Force. ${ }^{25}$ However, Smuts's plan was to increase these numbers as quickly as possible. ${ }^{26}$ Since the Defence Act of 1912 stated that both full-time and part-time soldiers could defend South Africa only within the borders of South Africa, it was necessary to institute the Africa Oath. ${ }^{27}$ The introduction of the Africa Oath, or Red Oath, increased numbers to such an extent that in the end, a total of 342792 full-time South African volunteers participated in the Second World War. ${ }^{28}$ 
At the outbreak of the war, Smuts was of the opinion that the danger lay far beyond the borders of South Africa. Volunteers who wanted to participate in the war had to note that service could be expected anywhere in Africa. Smuts made a promise in 1939 that all South Africans participating in the Second World War would only fight on the African continent. On 27 January 1943, however, he revoked this promise, and asked the House of Assembly for permission for South African soldiers to be sent to Europe. ${ }^{29}$ The motivation behind this is vague, but Liebenberg believes that Smuts's motivation lay in his wish that South Africans "should also make a significant contribution to the war on the continent of Europe". ${ }^{30}$ Regardless of the location to which these volunteers were sent, it is important to note that all volunteers had to take the General Service Oath (introduced in 1943). ${ }^{31}$ This oath implied that permanent members of the Defence Force could be called to serve outside the borders of South Africa. However, many members decided not to sign the Africa Oath or the General Service Oath because they believed it was their duty only to protect South Africa within the borders of the country. ${ }^{32}$ The participation in the war outside the borders of South Africa therefore merely involved volunteers. The volunteers who signed up for participation outside South African borders wore red tabs. ${ }^{33}$

The imposition of the Red Oath caused a rift in the people, ${ }^{34}$ and the wearing of the red tabs resulted in a physically visible separation between two groups. The first was Afrikaners and English-speaking whites in favour of South African participation in the Second World War (those wearing red tabs), and the second being Afrikaners who opposed participation (those not wearing red tabs). ${ }^{35}$ In short, the red tabs distinguished the "Smuts men" from the anti-war Afrikaners. ${ }^{36}$ This rift within the Afrikanerdom was also noticeable to the OB leaders, who on 20 August 1941 stated that they "perceive with anxiety the signs of an imminent split within the Afrikanerdom". ${ }^{37}$

The Germans were also aware of the internal turmoil in South Africa, especially within the Afrikanerdom. In propagandistic terminology, they described the anti-war Afrikaners' objections to war participation as follows, "[w]ith increasing indignation, the South Africans revolted against this oppression." ${ }^{38}$ Furthermore, Pasemann notes that Smuts was moving further away from the majority of Afrikaners' interests, "[i]n the course of his political work, Smuts moved farther and farther away from his own people, for whose needs, desires and struggles he showed less and less understanding." ${ }^{39}$ Despite the internal division and a clear Afrikaner sentiment against war participation, the number of Afrikaners who signed up to take part in the war was "surprisingly high". ${ }^{40}$ The Afrikaners who did form part of the pro-war group were in some instances motivated by economic conditions. According to Van der Waag, English-speaking whites participated for "King and country". ${ }^{41}$ On the other hand, OB member, JM de Wet, opined that many Afrikaners took the Africa Oath for "bread and butter as well as adventure". ${ }^{42}$ It should thus be made clear that wearing a red tab was not necessarily an indication of pro-British or pro-war sentiments, but rather that various contextual considerations also motivated Afrikaners to sign the Africa Oath. Nevertheless, the red tabs still caused a physical separation in the Afrikanerdom. 
Because of the growing anti-war sentiments, it was necessary for the Smuts government to use official propaganda. One of the goals was "not [to] alienate the Afrikaner segment of the population". ${ }^{43}$ Various techniques were utilised to achieve this objective, one of which is captured in the following quote:

Every time Oom Jannie Smuts appears on screen the commentary should be in Afrikaans. This will make people of both sections, including those who hold that this is only an English war, engineered by English capitalists, realise that it is an Afrikaner war too ... ${ }^{44}$

The Smuts government, therefore, had a conflicting goal when it came to Afrikanerdom during the war. On the one hand, the government wanted to appease the Afrikanerdom and get them involved in the war, and on the other, the government wanted to do everything possible to prevent and oppose Afrikaner resistance.

Smuts's motivation behind South Africa's participation in the Second World War is in itself ambiguous: "[f]rom every previous war, South Africa has emerged a greater country, and this war will prove no exception. Your work will further the tradition of Briton and Boer alike." 45 These words, part of Smuts's 1940 speech to soldiers on their way to North Africa, captured the ambiguity behind the government's wartime participation. The contradictory ideal that a war could benefit the Afrikaner as well as Britain at the same time caused a separation among the volk, and even in parliament. Van Rensburg himself was deeply affected by the government's decision to participate in the war, as his position as administrator of the Free State became increasingly difficult. By the end of 1940, Van Rensburg officially resigned as administrator. ${ }^{46}$ Van Rensburg clearly stated the motivation behind his decision to step down:

I had far too much respect for General Smuts to try to beat about the bush with him. I told him that to my mind I would be doing an injustice to both of us if I were to remain Administrator under his Government. All my loyalty was with General Hertzog and I was bitterly opposed to the Government's war effort. $^{47}$

The differing opinions in parliament were mainly between Hertzog and Smuts. Hertzog's position during the Second World War is summed up by Hans van Rensburg, "a man who was never against Germany, but who was always for South Africa ..." 48 The separation in parliament thus reflected the rift within the broader Afrikanerdom.

Apart from the separation that was present in parliament, Smuts's greatest concern lay in the OB. Smuts increasingly viewed the organisation as an underground and dangerous phenomenon. ${ }^{49}$ This concern would eventually be expressed in the implementation of various emergency regulations and war measures that closely affected the OB. A contemporary, OL Nel, also argued that the emergency regulations were specifically aimed at the OB:

It is noteworthy that the prosecution of Afrikaners by the Smuts government was directed almost exclusively at officers and members of the Ossewabrandwag. 
There were many Afrikaners, who are not members of the OB and who, to use the words of the Government are "anti-British" and "strongly opposed to the Government and its war effort" - and also made no secret of it - and yet they were not interned! ${ }^{50}$

Nel concluded that the introduction of the emergency regulations and the internment of various $\mathrm{OB}$ members were aimed at "beating the $\mathrm{OB}$ and causing it to die a natural death without officially banning it". ${ }^{51}$ It is a debateable - and somewhat baseless argument that the emergency regulations were directly aimed at the OB. For the purposes of this article, however, it is necessary to take into account that OB members believed this to be the truth.

Large numbers of $\mathrm{OB}$ members resisted the Smuts government's war effort, "especially as part of the Stormjaers [Storm Troopers]". ${ }^{52}$ As Blignaut clarifies, the resistance against South Africa's participation had been brought about in various ways. Violence, anti-war propaganda and passive resistance were all part of the domestic resistance to the Smuts government's war effort. ${ }^{53}$ Although it is taken into account that resistance does not always manifest in the form of violent actions, this article focuses mainly on the Smuts government's introduction of emergency regulations against domestic resistance and unrest. Because the emergency regulations were mostly directed against the violent elements, the focus of this article is only on violent and semi-violent domestic resistance. ${ }^{54}$

The OB believed that they had no other option than to use violence against the Smuts government. As OB leader Hans van Rensburg states, "violence was a last option" and that it should only be considered in response to the Smuts government's actions. ${ }^{55}$ Whatever the motivation behind the OB's resistance, Van Rensburg was of the opinion that the OB had a significant influence on the government. Van Rensburg justified this assumption using five separate arguments. First, he opined that the efforts made by these individuals hampered the government's war effort. ${ }^{56}$ As S Boshoff also recounted in 1979:

We were aware of the idea that we were out to sabotage Jan Smuts ... You just weren't agreeable with the war effort. As long as you can sabotage the war effort in any way possible, you have already fulfilled a certain task..$^{57}$

Van Rensburg's second argument maintained that the influence of these individuals (the saboteurs and activists) served to strengthen the sentiments of other individuals who were also opposed to the war. ${ }^{58}$

Thirdly, according to Van Rensburg, these individuals made the above impact with a "minimum sacrifice of lives and destruction of property" ${ }^{59}$ Van Rensburg made it clear that the purpose of the sabotage actions were to curb the government's war effort by keeping as many personnel in South Africa as possible. ${ }^{60}$ This sentiment is also supported by Hagemann ${ }^{61}$ and Robinson ${ }^{62}$ who believe that Van Rensburg and the OB, but especially the Stormjaers, aided Hitler's war efforts by keeping as many troops as possible in South Africa to stop domestic unrest. This argument, although 
widely supported, is somewhat baseless. The Smuts government set various plans into action for ensuring internal security without compromising the fighting forces and recruitment strategies of the UDF. For example, a voluntary organisation, later known as the Civilian Guards, was established to support the government in the preservation of internal security. ${ }^{63}$ To ensure that this organisation did not interfere with the UDF, volunteers were only considered if they were above the age of 45 , which was the limit for active enrolment in the UDF at that time. ${ }^{64}$ Although the OB and Van Rensburg might have been under the impression that widespread sabotage would have tied down large numbers of troops, this was not the case.

Fourthly, the actions of these individuals made the government aware of the idea that internal resistance is inevitable when a large number of civilians are opposed to the war. ${ }^{65}$ This argument by Van Rensburg is indeed correct. The fact remains, however, that the Smuts government took precautions and action against this "inevitable" resistance. The precautions and actions took on many forms, including the introduction of the War Measures Act (No. 13 of 1940), the establishment of the Civilian Guards, and the introduction of various internment camps for those who posed a threat to the internal security of South Africa. Fifth, Van Rensburg believed that this activism introduced the "close of an epoch". ${ }^{66}$ The epoch referred to is the struggle between Afrikaner nationalism and British imperialism, with the view that these two factions would rather work together against the "new danger". ${ }^{67}$

The effect of resistance by the Afrikanerdom, and especially the resistance by the $\mathrm{OB}$, was that the Smuts government felt justified in putting in place certain emergency measures. On 7 February 1940, Smuts officially received parliamentary approval to put emergency measures in place ${ }^{68}$ to "ensure the security of the state". ${ }^{69}$ However, it appears that the introduction of the emergency regulations was also motivated by several other driving forces. Terblanche argues that the Smuts government was "committed to prosecuting and victimising the national-minded Afrikaner who opposed the war". ${ }^{70}$ However, the motivations behind the emergency regulations of the Smuts government appear to have been deeper and more significant than anti-Afrikaner attitudes and aims of victimisation. The paragraphs below delve deeper into these motivations. What is undeniable, however, is that the introduction of these emergency regulations contributed to tensions between pro-war and anti-war groups. By November 1940, pro-war groups felt that insufficient action was being taken against the OB. On 1 November 1940, the Sunday Express for example, considered whether the OB should be banned because the latter would be in the interest of security in South Africa. ${ }^{71}$

Several violent events erupted between pro-war and anti-war individuals. The battle that broke out between soldiers and several OB members outside the Johannesburg City Hall on 31 January 1941 serves as a good illustration. ${ }^{72}$ The next evening, 1 February 1941, another violent riot broke out at the Voortrekker Building. ${ }^{73}$ A prowar group also attacked the headquarters of Die Vaderland (a prominent conservative Afrikaans newspaper). The motivation behind this attack was the misconception by some soldiers that the offices of Die Vaderland were the headquarters of the OB. ${ }^{74}$ The abovementioned violent actions reflect the strong emotions that existed between pro- 
war and anti-war factions. ${ }^{75}$ The violent actions that broke out between pro-war and anti-war factions between 31 January and 1 February 1941 could have turned into a massacre. ${ }^{76}$ Smuts's response to the violence was twofold. First, on 3 February 1941, he issued a Special Order to all troops. ${ }^{77}$ Second, Smuts appointed a Commission of Inquiry to investigate the events of both evenings. ${ }^{78}$ The recommendation and findings of this Commission were discussed in Parliament on 8 April 1941. ${ }^{79}$ The events of 31 January and 1 February led to significant growth for the $\mathrm{OB}$ as the events were widely covered by Afrikaans newspapers that mostly praised the OB members for their actions ${ }^{80}$ It also contributed to Van Rensburg's popularity. ${ }^{81}$

War often leads to several unwanted consequences for a nation. Even before the imposition of the Red Oath, Afrikaners were not united. This sentiment is summed up clearly by Van Rensburg's observation on the September 1939 war declaration, "[a] declaration of war always throws a nation into confusion, and rumour-mongering becomes rife overnight, even if the nation is united on the issue." 82 The entry into the war also caused old anti-British and anti-Smuts sentiments, based on the Great Trek (1834-1838), the First Anglo-Boer War (1880-1881), the Second Anglo-Boer War (1899-1902), the Rebellion (1914), and the Witwatersrand Rebellion (1922) to flare up within the Afrikanerdom. ${ }^{83}$ Although Smuts's reputation as a statesman of the world grew - especially as the Allied war effort has been so successful - his support among Afrikaners steadily declined. The reason behind this was "the growing conviction that he no longer had the interests of the Afrikanerdom at heart". ${ }^{84}$ This idea became increasingly popular among Afrikaners, and ultimately contributed to the outcome of the 1948 election.

A great deal of anti-Smuts sentiment is rooted in Smuts's undeniable pro-British sentiments. Even the German political magazine Zeitschrift für Politik described Smuts as follows, "[o]ne of the strongest pillars of the British Empire to date is Mr. Smuts, today's Prime Minister of the South African Union." 85 The friendship Smuts had with the Royal Windsor family ${ }^{86}$ and the friendship between him and Winston Churchill a friendship that lasted for almost 50 years $^{87}$ - are examples of Smuts's pro-British sentiments. The friendship between Smuts and Churchill was such that Churchill's wife, Clementine Churchill, wrote, "[h] e really cares for Winston, and is a great source of strength and encouragement to him." 88 Smuts himself admitted during a speech before the British Parliament that he regarded Churchill very highly:

I sometimes wonder whether people in this country sufficiently realise what Winston Churchill has meant and continues to mean not only to them but also to the Allied peoples, the United Nations, and to the brave men and women everywhere in the world. ${ }^{89}$

Smuts's close connection with Britain became increasingly clear to the Afrikanerdom during the Second World War. It is undisputed that Afrikaners' observations about Smuts had a drastic outcome on domestic resistance. In some instances, the government viewed anti-British sentiments as enough reason for internment and arrest under the emergency regulations. ${ }^{90}$ 
Smuts's close ties with Britain and general pro-English attitude had a clear effect on the Afrikanerdom during the Second World War (see Figure 1). The separation that was increasingly evident among the people eventually led to the Smuts government instituting various war measures. In the end, it seems that the Smuts government had considered the introduction of emergency regulations a matter of home security and safety. However, several other motivations are also clear, such as -

- the idea that Smuts was doing everything in his power to assist the British Empire in their war effort against Germany; and

- the impression that the OB posed a real danger to the government, especially as the organisation began to flourish progressively more in the political arena, mainly after Van Rensburg took over as commander in chief of the organisation in January 1941.

The introduction of the emergency regulations did not necessarily dampen the resistance to the war effort, but rather fuelled it. Next, the nature and extent of the emergency regulations are discussed in order to determine how its implementation affected the OB.

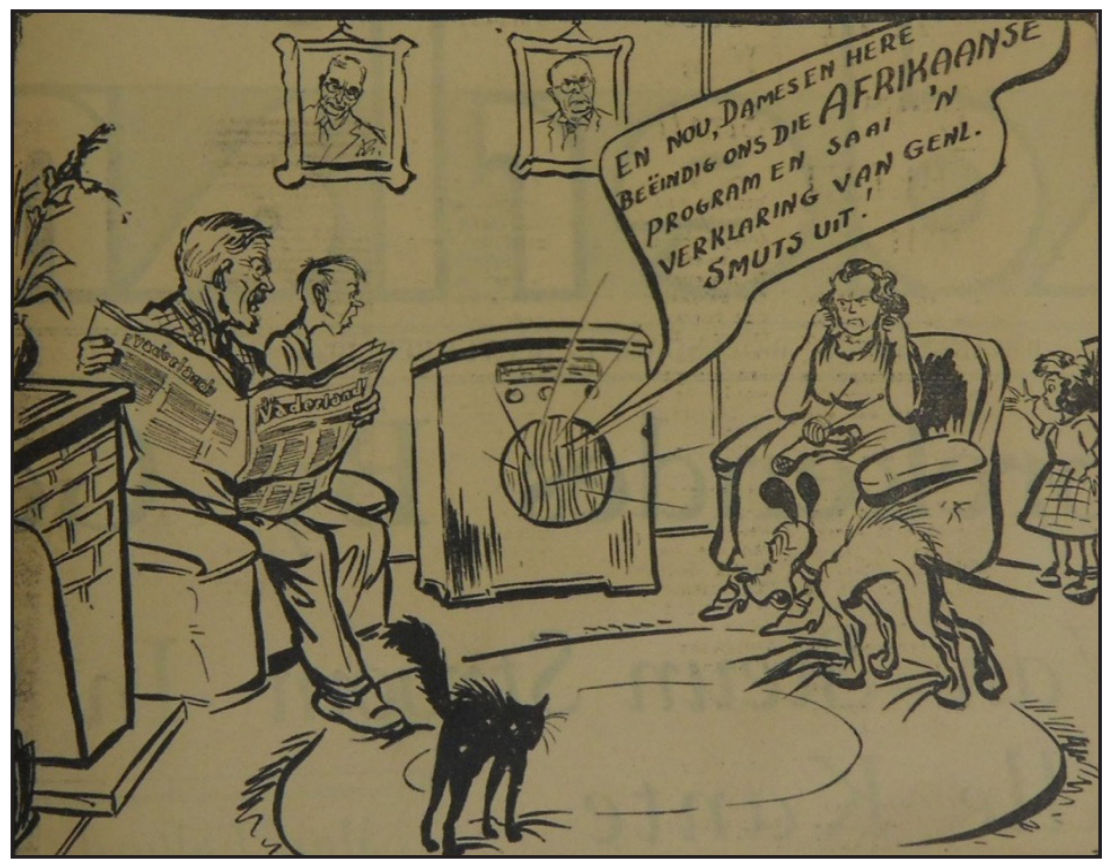

Figure 1: Cartoon mocking Smuts's pro-British sentiments, circa October $1939^{91}$ 


\section{Nature and extent of the war measures and emergency regulations}

South Africa entered the war without the population voting on the issue. O'Meara argues that, if the white population had been allowed to vote on the issue of war participation, the result would probably have been against war participation. ${ }^{92}$ This argument was sustained by anti-war individuals and groups during the war. ${ }^{93}$ Because the Afrikaner had no voice in the decision to participate in the war, several anti-war factions arose. This included anyone who opposed the Smuts government's decision, whether it was by means of passive or active resistance.

Due to the various activities that arose in anti-war factions, it was necessary for the government to put in place a number of emergency regulations that expanded and increased over time. As already discussed, the Smuts government had several ways to justify the introduction of these regulations, but it is important to reflect on the nature and scope of these regulations. As Monama puts it, the underground anti-war activities contributed to a variety of regulations being put in place:

Although South Africa was geographically removed from the main theatre of military operations, the multiple security, publicity and propaganda measures reflected the impact of the war conditions, especially given the country's political fractures and societal divisions on the basis of race, class and also gender. The activities of the extra-parliamentary movements, subversive operations, sabotage, and declining morale among the Union troops as well as the prevalence of the social and economic tensions, required the authorities to adopt various measures to maintain control and authority. ${ }^{94}$

The tension that Monama mentions started long before the war, but was exacerbated during the war. This increase in social, political and economic pressure elicited a "more extremist response" from the Smuts government. ${ }^{95}$

The first set of emergency regulations was announced only fourteen days after the declaration of war. This set of emergency regulations allowed appointed senior executives to prohibit meetings that are not of a religious nature. ${ }^{96}$ The government also dampened the power of groups to organise themselves militaristically by introducing Proclamation 201 of $1939,,^{97}$ as well as the 1940 War Measures Act (No. 13 of 1940). ${ }^{98}$ Although these regulations were not strictly enforced immediately, the emergency regulations were systematically developed and expanded to include various elements. ${ }^{99}$

According to Van der Walt, the purpose of the emergency regulations was to "detect underground movements and intimidate the anti-war elements". ${ }^{100}$ Despite this observation by Van der Walt, it is safe to believe that the emergency regulations had several motivations other than the detection and intimidation of underground and antiwar factions. Under Emergency Regulation 15 of 14 September 1939 as well as War Measure 47 of 10 December 1941, any individual suspected of underground activities or anti-war attitudes could be interned. ${ }^{101}$ The internment closely affected several ordinary and prominent members of the OB. The impact of the war measures - and 
more specifically the large-scale internment - is given further attention in the next section. In addition to internment, emergency regulations affected various other aspects of everyday life. For example, under the emergency regulations, wearing of uniforms by citizens was strictly prohibited. ${ }^{102}$ Furthermore, several special courts were set up to prosecute political crimes. ${ }^{103}$ Taking into consideration that the OB as well as other movements, such as Oswald Pirow's New Order and the anti-Semitic Gryshemde (Grey Shirts), were increasing their militant nature, the steps taken against citizens wearing uniforms were both justifiable and necessary.

A further embodiment of the emergency regulations was to claim all private firearms under Proclamation 139 of $1940 .{ }^{104}$ The motivation behind this was possibly to prevent an armed uprising. Nevertheless, the Smuts government maintained that the motivation behind this was that the government needed the weapons in the war against Germany. ${ }^{105}$ By August 1940, about 88000 firearms had already been confiscated. Many more would follow, as the war would last until 1945. ${ }^{106}$ The war measures also affected OB members' employment within the public service. In terms of Proclamation 20 of 1941, the government decided to institute a war measure that prevented all civil servants from being OB members. ${ }^{107}$ This war measure "provides that no officer, whether Union, Provincial or Railway official, may remain a member of the Ossewa-Brandwag or participate in its pursuit or proceedings" or "support its policy". ${ }^{108}$ The measure further required all public servants to "terminate their [Ossewa-Brandwag] membership within fourteen days". ${ }^{109}$ This new measure directly affected OB members who were in the police force. ${ }^{110}$ Van Rensburg reacted to this by "honourably dismissing all civil servants" from the OB. ${ }^{111}$ According to the official order, the OB saw the motivation behind Proclamation 20 of 1941 as twofold: firstly to "break" the Ossewa-Brandwag and, secondly, to "purify the Public Service of Afrikaner-minded personnel". ${ }^{112}$ The OB's motivation behind the honourable dismissal of all public servants seemed to be people-oriented and economically responsible: "[i]t is not in their [public servants'] interest nor in the interests of Afrikanerdom that they be thrown into the street with wife and child without that sacrifice promoting our cause." 113

In a special report to the government, the Commissioner of Police disclosed substantial information about sabotage actions and the Stormjaers. ${ }^{114}$ The Stormjaers was a secret organisation within the $\mathrm{OB}$, while the $\mathrm{OB}$ was not illegal or secretive in nature. ${ }^{115}$ The Stormjaers can be best described as a "circle within a circle". ${ }^{116}$ The special report reads, "[i]n these circumstances it is again stressed that the Ossewabrandwag organisation is a grave danger and should be immediately banned." 117 According to Visser, the only immediate response to this was the passing of a special law, which was enacted on 4 February 1942, that formed part of the emergency regulations. In short, the law stated that any individual who used explosives in the resistance movement against the government could be sentenced to death. ${ }^{118}$

As Visser states, the OB was under the impression that they were the true Afrikaners, the "patriots", while the rest of the pro-war Afrikaners were the "traitors". ${ }^{11}$ The Stormjaers offered "active resistance to the war effort" and consequently both secrecy and weapon ownership were crucial. ${ }^{120}$ Nevertheless, for the purposes of this article, it 
is necessary to take into account that the OB and the Stormjaers were not synonymous, "the relationship between the OB and the Stormjaers was complex". ${ }^{121}$ Although the Stormjaers emerged from the OB, the Stormjaers subsequently developed on their own. ${ }^{122}$ As already mentioned, the dynamic between the Stormjaers and the OB was complicated, and can undoubtedly be the focus of numerous research endeavours in the future.

The Smuts government's efforts to curb domestic resistance thus sparked a vicious cycle, a cycle in which every action of every anti-war faction was met with resistance by the government and, in turn, every action of the government was met with reaction by the anti-war faction. Van Rensburg did not view the sabotage actions of OB members as acts of violence, but rather as "violent reactions" against the internment and arrest of fellow OB comrades. ${ }^{123}$ Robinson supports Van Rensburg's position in a 1988 leaflet on an OB Museum exhibition. Robinson also believed that the sabotage actions "were committed as a sign of protest against the government's internment policy". ${ }^{24}$ The nature and extent of the war measures and emergency regulations, therefore, became closely related to the $\mathrm{OB}$ and the broader Afrikanerdom. The above paragraphs should serve as proof that the emergency regulations took various forms. By viewing it kaleidoscopically, it is possible to understand its nature and scope better. The exact impact of the measures and regulations is explored in depth in the next section.

\section{Impact of war measures and emergency regulations on $\mathrm{OB}$ members}

The impact of the war measures and emergency regulations on $\mathrm{OB}$ members is a significant aspect of South African history. Despite its decisive contribution to history, several aspects have not yet been explored. An example of this is the high treason cases against Afrikaner saboteurs operating during the Second World War. With the exception of Robey Leibbrandt, ${ }^{125}$ these aspects of the South African experience of the Second World War have been "largely forgotten". ${ }^{126}$ It is for this reason, as Blake rightly notes, that the history surrounding these saboteurs should again be placed on the historical agenda. Part of this history is not only how the emergency regulations affected the saboteurs, but also the $\mathrm{OB}$ as an organisation, as well as its members.

The impact of the emergency regulations on the OB was felt throughout the Second World War. On 1 February 1940, the commander in chief of the OB at that time (Colonel JC Laas) received a letter from an OB member, Mrs JE Theron, in which she highlighted various concerns about the $\mathrm{OB}$ as an organisation and requested answers. She cited her Afrikaner nationalism as the reason behind her concerns. ${ }^{127}$ Laas's response to Theron's letter clearly indicated the difficult position of the $\mathrm{OB}$ at the time. In a challenging political domestic climate, in the midst of a world war, the OB had to strengthen itself

as a newly created organisation of less than two years old. Laas answered Theron as follows:

Just don't lose sight of the fact that our organization is still in its early stages, and we need all the love and sympathy of our people to make it a success, otherwise it can fail so easily, and our enemy will be heartily victorious. They 
are already well aware that here is an element to be taken into account, because no one can deny that we are on track to seize the people's hearts and interests, and our one hope is that the Afrikaner suicide weapon of "division" will not succeed in cleaving again. ${ }^{128}$

There can be no doubt that the introduction of the Smuts government's emergency regulations affected the $\mathrm{OB}$ as an organisation. With the introduction of the emergency regulations, several prominent members of the $\mathrm{OB}$ were interned as early as May 1940. ${ }^{129}$ Laas's observation that the government was aware that the OB was "an element to be taken into account" was therefore accurate. ${ }^{130}$ On 17 June 1940, Die Burger (a local newspaper) reported that about 1600 people were being held in camps. ${ }^{131}$ By 12 November 1940, that figure had more than doubled to about 4000 people. This included Italian and German prisoners of war and South African internees. ${ }^{132}$

However, the OB only started to get involved at a political level in 1940. Several factors contributed to this swing towards becoming a dualistic organisation. These factors included (but were not limited to):

- $\quad$ the Smuts government's decision to partake in the war;

- the confiscation of private arms;

- $\quad$ the detention of several OB members (especially Stormjaers) in internment camps;

- $\quad$ police raids; and

- $\quad$ the effect internment had on various OB families who were suddenly left without a breadwinner. ${ }^{133}$

All these, along with various other emergency regulations, affected the $\mathrm{OB}$ as an organisation as well as its members. The internment caused great bitterness within the Afrikanerdom, as OL Nel says:

If the methods of the Smuts government are studied from all sides, one gets the impression that the motive was to keep certain Afrikaners behind barbed wire and the question of whether they were guilty, or innocent, was not even mentioned at all. ${ }^{134}$

A further tantalising point for the internees and political prisoners was that the reasons for internment and the handling of appeals against internees often extended over long periods, ${ }^{135}$ as Nel puts it:

The fact that some interns had to wait up to six months to get their "reasons" for internment and more than twelve months before their "appeal" was finalised is proof enough that there was no rush at all to release the men. ${ }^{136}$

As already mentioned, the families of internees were severely affected by internment, especially when the internment lasted for months without any stated reason on the part of the government. With the internment of OB members, several households were left 
without any source of income. ${ }^{137}$ The OB was affected by this because several members (especially women and children) were left without money. The impact of the internment in this case resulted in the formation of the Noodhulpfonds (Distress Relief Fund). In short, the Noodhulpfonds was primarily established with the aim to provide and care for the families of internees, political prisoners and fugitives. ${ }^{138}$ The aim of this article is not to delve into the Noodhulpfonds. It is, however, necessary to take into account that the emergency regulations affected not only saboteurs and activists, but also the families of these individuals. As an organisation, the OB was in this sense also affected because members had to find a way to "support the wives and children of the internees". ${ }^{139}$

It is therefore clear that not only the Stormjaers and ordinary OB members were directly affected by the measures, but also their families. The 1940 women's march, which involved about 9870 women, reflected the unity that emerged within the OB and the broader anti-war Afrikanerdom. The women's march mainly revolved around the implementation of the Africa Oath and the fact that some Afrikaners did not want to sign the oath (see Figure 2). ${ }^{140}$ The demonstration also embodied the opinion that South Africa's participation in the war could not have made a significant difference, so there was no need to jeopardise the lives of several soldiers unnecessarily. ${ }^{141}$

Men who refused to sign the Africa Oath were put under immense pressure and were exposed to the danger of possibly losing their jobs. The women's march of 1940 symbolised women's support for their husbands and sons not to sign the Africa Oath merely out of fear of dismissal. ${ }^{142}$ A petition for neutrality was presented by a deputation of three women at the Union Buildings. JH Hofmeyr, Minister of Finance and acting Prime Minister in Smuts's absence, received the petition. ${ }^{143}$ There were more to women's involvement than only the march and petition. Other petitions were signed, and several telegrams were sent. This allowed Afrikaner women to express their views on South Africa's decision to partake in the war. ${ }^{144}$ However, the government did not respond to these petitions because it was "contrary to the decisions of Parliament", according to Smuts. ${ }^{145}$ The women's march should therefore be seen as proof that the emergency regulations had affected not only the radical OB members, but also the women in the organisation. 


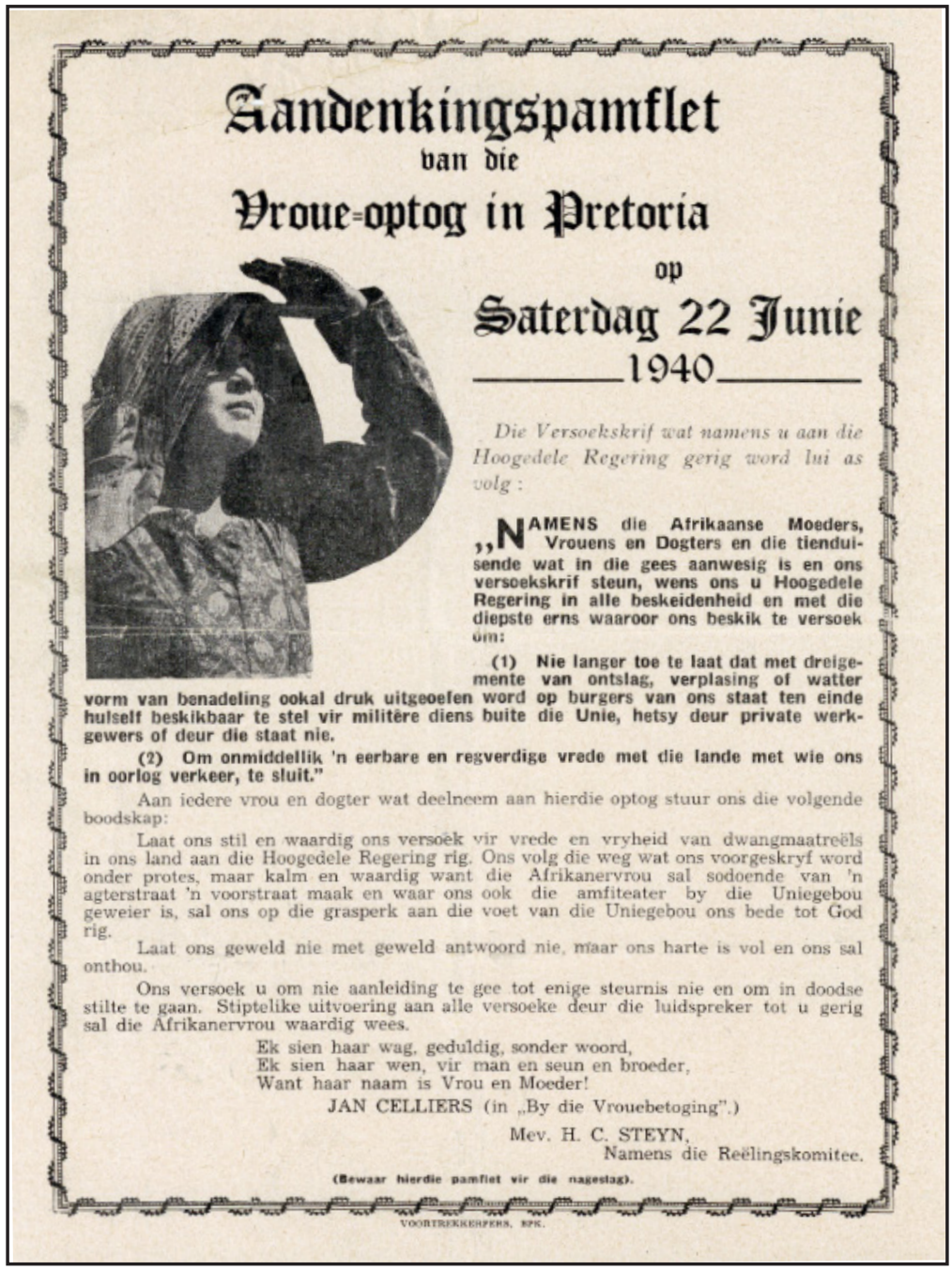

Figure 2: Leaflet commemorating the Women's March of 22 June 1940 in Pretoria. The leaflet contains the petition addressed to the Union Government. ${ }^{146}$

In addition to the large-scale internment of several members of the $\mathrm{OB}$, as well as the fact that several members refused to sign the Africa Oath, the organisation was also affected by rumours and accusations by the government against the organisation. The problem was already visible in 1940 under Laas's leadership. ${ }^{147}$ The OB Groot Raad (High or Supreme Council) and Colonel Laas protested against such statements and 
sent a letter to Smuts. ${ }^{148}$ Although the spreading of rumours and accusations did not officially form part of the emergency regulations, it was still an example of the effect that the actions by the Smuts government had on the OB. Rumours and allegations were quickly converted into action, for example, the government set up various committees to investigate espionage and Nazi links within Afrikaner organisations, such as the OB. The OB's strong militancy and rapid growth made it one of the main focal points for the government's internal security investigations. ${ }^{149}$ Intelligence reports from these committees revealed pro-German sympathies and even interaction between OB members and Nazi secret agents. These reports and rumours led to anxiety within the government regarding Nazi infiltration within South Africa, which in turn led to various police raids and the spreading of more rumours pertaining to the OB's links with Germany. ${ }^{150}$

In 1941, under the leadership of Van Rensburg, the problem of false rumours continued to be an issue within the OB. Van Rensburg and the Groot Raad decided to act. In Public Order number 1/41, it was stated that "a defence organisation" was formed to investigate "rumours and accusations against the Ossewa-Brandwag movement, or against prominent leaders of our people". ${ }^{151}$ Each commander within the OB had to nominate an officer to "report in writing" these rumours and accusations. ${ }^{152}$ This officer had to hold the rank of field cornet and was known as the "information field cornet". ${ }^{153}$ Order number 31/41 of the OB's Cape branch also announced a policy on reports, allegations and inquiries regarding the OB. This order required that "any allegation, whisper story or attack directed at the Ossewabrandwag" and higher officers should be reported immediately. ${ }^{154}$ This illustrates that the government's actions during the wareven actions that did not specifically form part of the emergency regulations - directly affected the $\mathrm{OB}$ as an organisation.

The war participation and subsequent war measures also negatively affected the relationship between the National Party (NP) and the OB. The rift between the NP and the OB is evident in the letters sent to Van Rensburg. On 8 September 1941, JHH de Waal, a Pretoria attorney and an ardent OB member, said that the OB should no longer tolerate the actions of DF Malan (leader of the NP at the time). De Waal asked whether an "order can be issued that all OB members also resign from the party of which such a villain is the leader". ${ }^{155}$ Meanwhile, Malan and the NP initially tried to maintain a relationship with the OB. In a letter Malan sent to Van Rensburg on 24 November 1941, it appeared that the motivation behind this collaboration was in the interest of the Afrikaner volk. Malan urged Van Rensburg to work together to fight the divide within the "national-minded Afrikanerdom", and to avoid the "total destruction" thereof. ${ }^{156}$ The upcoming election of 1943 only added to the tension between the OB and the NP. The OB tried to distance itself from the 1943 election by maintaining that party politics should be considered an "imported British [political] system" that is "unnatural to the Afrikaner". ${ }^{157}$ Van Rensburg stated that the OB had "no obligation and no need" to entangle itself in the political drama of the election. ${ }^{158}$ Despite the OB's attempts to distance itself from the election, it still had significant influence amongst the Afrikaner segment of the voting public, and thus found itself amidst the political drama without being a political party. 
In addition to the rift between the NP and the OB, the war participation and measures also had an effect on several activist OB members, especially the Stormjaers. Members of the Stormjaers were regularly charged with treason, for example in 1942, a total of 58 Stormjaers were charged. ${ }^{159}$ Examples of Stormjaers charged with treason include the infamous J Visser and $\mathrm{H}$ van Blerk saga, both of whom were arrested under the emergency regulations in connection with the May 1942 bombing of the Benoni post office, in which a young male passer-by died. ${ }^{160}$

Subsequently, both Visser and Van Blerk were sentenced to death for the Benoni bombing. ${ }^{161}$ Pressure was put on the government by various sources to reconsider the death penalty of these individuals. On 1 August 1942, it was announced that the death penalty of both individuals was changed to life imprisonment. ${ }^{162}$ According to Fourie, the motivation behind this decision was threefold:

- $\quad$ first, Smuts did not want to turn Visser and Van Blerk into Afrikaner martyrs;

- $\quad$ second, the upcoming election (1943) served as motivation not to turn the Visser-Van Blerk saga into a political weapon; and

- $\quad$ third, Smuts was aware that the execution of these individuals could lead to an increase in domestic unrest. ${ }^{163}$

Another example of a commuted sentence by the Smuts government was evident in the sentencing of Robey Leibbrandt. Leibbrandt is best known as a South African Olympic boxer who participated in the 1936 Berlin Olympic Games. Leibbrandt returned to Germany two years after the Olympics and later joined the German Army's war effort. ${ }^{164}$ In 1941, Leibbrandt was ordered to head Operation Weissdorn, a secret operation aimed at overthrowing the Smuts government. In the attempt to do so, Leibbrandt tried to make contact with the OB, and more specifically the Stormjaers, but OB leader Hans van Rensburg was indifferent towards Leibbrandt. After failed attempts to infiltrate the Stormjaers, Leibbrandt formed an organisation known as the Nasionaal Sosialistiese Rebelle (National Socialist Rebels). The organisation managed some sabotage actions against the Smuts government's war effort but nothing close to Operation Weissdorn's aim of a coup d'état. Leibbrandt was eventually arrested and tried for high treason. On 11 March 1943, Leibbrandt was sentenced to death. ${ }^{165}$ As in the case of Visser and Van Blerk, the initial death sentence was commuted to life imprisonment. ${ }^{166}$

After the war, Afrikaner unity slowly started to mend. With the assistance of cultural organisations like the Afrikaner Broederbond (Afrikaner Brotherhood], national unity (volkseenheid) was once again on the rise. ${ }^{167}$ Despite the rift between the OB and the $\mathrm{NP}$, as well as the unique placing of Leibbrandt within the internal turmoil in South Africa during the Second World War, several political prisoners obtained their freedom after the 1948 election under NP rule, including Visser, Van Blerk and Leibbrandt. ${ }^{168}$ The declaration to release political prisoners was officially issued on 11 June $1948 .{ }^{169} \mathrm{In}$ 1948, with the success of the National Party, Afrikaner unity and Afrikaner nationalism, which had gone through a strong division during the war, were systematically restored. ${ }^{170}$ 


\section{Evaluation: Justifying the emergency regulations and the impact thereof on the OB}

Nel concluded that the introduction of the emergency regulations and the internment of various $\mathrm{OB}$ members were aimed at "beating the $\mathrm{OB}$ and, if necessary, letting it die a natural death without banning it". ${ }^{171}$ From Visser's observation, it seems that Smuts strategically controlled the OB during the Second World War, as "[m]ore active interest would only have served to consolidate and strengthen the OB and perhaps create unwarranted martyrs." ${ }^{\prime 12}$ What Visser failed to observe, was that the Smuts government nevertheless managed to create martyrs through the implementation of the emergency regulations and especially the internment policy. Some of these emergency regulations were considered "tyrannical" by many Afrikaners, ${ }^{173}$ who opposed these measures with resistance, creating a general climate of resistance, which was met in turn with more measures to ensure internal security.

The effective implementation of emergency regulations ensured that the internal security of South Africa was maintained adequately during the war, and despite some internal sabotage, the Smuts government's war effort was mostly unhindered by the internal resistance. With a German defeat evident near the end of the war, the OB's collapse as a political force within the Afrikanerdom became inevitable. Ironically, the war, which initially served as a catalyst for the OB's popularity within the political sphere of the Afrikanerdom, eventually contributed to the steady demise of the organisation. Like many other quasi-military organisations, most of the OB's members were absorbed into the NP.

The Smuts government's emergency regulations directly and indirectly affected a large number of people. However, Smuts could have done much more to the internal turmoil if he wanted to. The reason why nothing more was done could possibly be attributed to a desire to prevent a full-scale rebellion or civil war. ${ }^{174}$ Whatever the case, it is clear that Smuts's actions towards domestic unrest during the Second World War provoked hostility among Afrikaners. The manifestation of this hostility towards Smuts was evident in the election results of 1948. On 28 May 1948, two days after Smuts's defeat in the general election, Van Rensburg wrote to Smuts stating that he "contributed to some extent" to the defeat that Smuts had just suffered. ${ }^{175}$ Various socioeconomic conditions, as well as the popularity of the NP's racial segregation policy, also contributed to the 1948 election results.

This article does not maintain that the NP's electoral victory can be attributed solely to Smuts's emergency regulations, but rather argues that the actions of the Smuts government during the war provoked hostility amongst the Afrikaner segment of the voting public. In this sense, the implementation of the emergency regulations altered the political landscape for the Afrikanerdom. During the war, the OB, as an anti-British and pro-Afrikaner organisation, operated within a complex socio-political landscape. It was not unique in its pro-Afrikaner stance or in its anti-war sentiments, but rather functioned like many other Afrikaner structures that also catered for the needs and desires of the general Afrikanerdom. The rift within the Afrikanerdom of the early 1940s gradually 
started to mend after the war with the "cooperation of various Afrikaner powers" and political driving forces, ${ }^{176}$ reaching a significant climax with the NP's electoral victory in 1948. As the 1948 election shaped the South Africa known today, it is important to reflect on the role players such as the $\mathrm{OB}$ and Smuts played in the outcome of that result. 


\section{ENDNOTES}

${ }^{1}$ Anna La Grange is currently affiliated with the North-West University (NWU). She completed her MA in History degree (cum laude) at the NWU in 2020. She also completed her BA degree in Heritage and Cultural Tourism Management (cum laude) in 2016, and a BA Honours degree in History (cum laude) in 2017, both at the NWU. Apart from research and teaching, she is also very passionate about archives, including archival organisation, research on archives and research on the future of archives that stems from her participation in the processing of the Ossewa-Brandwag Archive in Potchefstroom.

${ }^{2}$ WK Hancock. Smuts: The fields of force, 1919-1950. Cambridge: Cambridge University Press, $1968,331$.

${ }^{3}$ A Blake. Wit terroriste: Afrikaner-saboteurs in die Ossewabrandwagjare. Cape Town: Tafelberg, 2018, 92. Quotes have been translated from Afrikaans.

${ }^{4}$ Ibid., p. 92.

${ }^{5}$ A Grundlingh. "The King's Afrikaners? Enlistment and ethnic identity in the Union of South Africa's Defence Force during the Second World War, 1939-45". The Journal of African History 40/3. 1999. 353.

${ }^{6}$ Ibid., p. 354.

${ }^{7}$ Hancock op. cit., p. 308.

${ }^{8}$ Ibid., p. 314.

${ }^{9}$ For a recent publication on Smuts, see JA du Pisani, D Kriek \& C de Jager (eds). Jan Smuts: Van Boerseun tot wêreldverhoog. Pretoria: Protea Boekhuis, 2017.

${ }^{10} \mathrm{O}$ Geyser. Jan Smuts and his international contemporaries. Johannesburg: Covos Day, 2001, xxi.

${ }^{11} \mathrm{H}$ van Rensburg. Their paths crossed mine. Cape Town: Central News Agency, 1956, 73.

${ }^{12}$ For a general idea of the history of the OB, see AJH van der Walt. ' $n$ Volk op trek: ' $n$ Kort geskiedenis van die ontstaan en ontwikkeling van die Ossewa-Brandwag. Johannesburg: Publicité, 1941; HG Stoker (ed). Agter tralies en doringdraad. Stellenbosch: Pro Ecclesia, 1953; Van Rensburg op. cit.; GC Visser. OB: Traitors or patriots? Johannesburg: Johnathan Ball, 1976; PF van der Schyff (ed). Geskiedenis van die Ossewa-Brandwag. Unpublished report. Department of History, PU for CHE, 1984; P de Klerk. "Afrikanerdenkers en die beginsels van die Ossewa-Brandwag". Journal for Contemporary History 14/1. 1989. 43-81; PF van der Schyff (ed). Die Ossewa-Brandwag: Vuurtjie in droë gras. Potchefstroom: PU for CHE, 1991; C Marx. "The Ossewabrandwag as a mass movement, 1939-1941". Journal of Southern African Studies 20/2. 1994. 195-219; C Marx. Oxwagon Sentinel: Radical Afrikaner nationalism and the history of the Ossewa-Brandwag. Pretoria: Unisa Press, 2008; C Blignaut. "Volksmoeders in die kollig: Histories-teoretiese verkenning van die rol van vroue in die Ossewa-Brandwag, 1938 tot 1954". MA thesis. North-West University, 2012; C Blignaut. "'Die hand aan die wieg regeer die land [The hand that rocks the cradle rules the land]': Exploring the agency and identity of women in the OssewaBrandwag, 1939-1954". South African Historical Journal 67/1. 2015. 47-63.

${ }^{13}$ Marx, Oxwagon Sentinel ... op. cit.; Marx, "The Ossewabrandwag as a mass movement ..." op. cit.

${ }^{14}$ AM Fokkens. "Afrikaner unrest within South Africa during the Second World War and the measures taken to suppress it". Journal for Contemporary History 37/2. 2012. 123-142.

${ }^{15}$ Ibid., pp. 123-142.

${ }^{16}$ PJ Furlong. Between crown and swastika: The impact of the radical right on the Afrikaner nationalist movement in the fascist era. Johannesburg: Witwatersrand University Press, 1991. 
${ }^{17}$ Hancock op. cit., p. 330.

${ }^{18}$ Ibid., p. 330.

${ }^{19}$ Visser op. cit., p. 13; O Geyser \& LCA Pruis. Die Suid-Afrikaanse politieke geskiedenis in beeld. Bloemfontein: Instituut vir Eietydse Geskiedenis Publikasie, 1976, 47; Blake op. cit., p. 40.

${ }^{20}$ FL Monama. "Wartime propaganda in the Union of South Africa, 1939-1945". PhD dissertation. Stellenbosch University, 2014, 4; FL Monama. "South African propaganda agencies and the battle for public opinion during the Second World War, 1939-1945". Scientia Militaria 44/1. 2016. 147; Visser op. cit., p. 13.

${ }^{21}$ LM Fourie. "Die Ossewa-Brandwag in die Suid-Afrikaanse politiek, 1939-1952". In PF van der Schyff (ed), Geskiedenis van die Ossewa-Brandwag. Unpublished report. Department of History, PU for CHE, 1984, 2-3.

${ }^{22}$ Hancock op. cit., p. 324. The precautions taken would manifest themselves in the form of various war measures and the emergency regulations.

${ }^{23}$ Blake op. cit., p. 57.

${ }^{24}$ A Lentin. Jan Smuts: Man of courage and vision. Johannesburg: Jonathan Ball, 2010, 137.

${ }^{25}$ Visser op. cit., p. 30.

${ }^{26}$ BJ Liebenberg. "Van die Statuut van Westminster tot die Republiek van Suid-Afrika, 19311961”. In CFJ Muller (ed), 500 jaar: Suid-Afrikaanse geskiedenis. Pretoria: Academia, 1968, 380.

${ }^{27}$ Grundlingh op. cit., p. 362.

${ }^{28}$ I van der Waag. A military history of modern South Africa. Johannesburg: Jonathan Ball, 2015, 175. For more information on the racial distribution of the volunteers, see Van der Waag op. cit., p. 176. The white participation in the war can be further divided into Afrikaans speakers and English speakers.

${ }^{29}$ Liebenberg op. cit., p. 381.

${ }^{30}$ Ibid., p. 381. Translated from Afrikaans.

${ }^{31}$ Van der Waag op. cit., p. 175; Visser op. cit., pp. 30-31.

${ }^{32}$ Visser op. cit., p. 31.

${ }^{33}$ Van der Waag op. cit., p. 175.

${ }^{34}$ K Shear. "Tested loyalties: Policies and politics in South Africa, 1939-63". Journal of African History 53/2. 2012. 179; H Strydom. Vir volk en Führer: Robey Leibbrandt \& Operasie Weissdorn. Johannesburg: Jonathan Ball, 1983, 1.

${ }^{35}$ Liebenberg op. cit., p. 382.

${ }^{36}$ Hancock op. cit., p. 333.

${ }^{37}$ Ossewa-Brandwag Archive (hereafter OBA), Kommandant-Generaal collection, 2/4, file 19: Correspondence, 20 August 1941. Translated from Afrikaans.

${ }^{38}$ ME Pasemann. "Jan Christiaan Smuts". Zeitschrift für Politik 30. 1940. 114. Translated from German.

${ }^{39}$ Ibid., p. 116. Translated from German.

${ }^{40}$ Grundlingh op. cit., p. 354.

${ }^{41}$ Van der Waag op. cit., p. 175. This sentiment is also reflected by Lambert, who states that white English-speaking South Africans "had taken great pride" in the Union's participation in the war. See J Lambert. “"Their finest hour?' English-speaking South Africans and World War II". South African Historical Journal 60/1. 2008. 80.

${ }^{42}$ OBA, Tape recordings, interview transcript, tape number 9, 1973: HM Robinson/HC van Rooy/ JM de Wet, 2. Translated from Afrikaans.

${ }^{43} \mathrm{~S}$ Chetty. "Imagining national unity: South African propaganda efforts during the Second World War". Kronos 38/1. 2012. 120.

${ }^{44}$ As seen in Ibid., p. 120, originally seen in EG Malherbe. "Recognition of the Afrikaans element in propaganda", EG Malherbe collection, KCM 56974 (544), File 438-11 KCAL. 
${ }^{45}$ Quote taken from Geyser \& Pruis op. cit., p. 53.

${ }^{46}$ Visser op. cit., p. 15.

${ }^{47}$ Van Rensburg op. cit., p. 166.

${ }^{48}$ Ibid., p. 26.

${ }^{49}$ Van der Waag op. cit., p. 174.

${ }^{50} \mathrm{OL}$ Nel. Agter die doringdraad in Koffiefontein. Johannesburg: L\&S Boek- en Kunssentrum, 1948, 56-57. Translated from Afrikaans.

${ }^{51} \mathrm{Ibid}$., p. 57. Translated from Afrikaans.

${ }^{52} \mathrm{C}$ Blignaut. “'Goddank dis hoogverraad en nie laagverraad nie!': Die rol van vroue in die Ossewa-Brandwag se verset teen Suid-Afrika se deelname aan die Tweede Wêreldoorlog". Historia 57/2. 2012. 84. Translated from Afrikaans.

${ }^{53}$ Blignaut, "Volksmoeders in die kollig ..." op. cit., p. 206.

${ }^{54}$ For more information on passive resistance, especially among women in OB, see Ibid., pp. 206-237. To find out more about the anti-war propaganda distributed during the war, see C Marx. "'Dear listeners in South Africa': German propaganda broadcasts to South Africa, 1940-1941". South African Historical Journal 27/1. 1992. 148172; Monama, "Wartime propaganda ..." op. cit.; also Monama, "South African propaganda agencies ...”op. cit., pp. 145-167.

${ }^{55}$ Briefly touched upon by A Venter. "Die politieke oortuigings van Hans van Rensburg (1898-1966): Kontinuïteit en verandering”. Tydskrif vir Geesteswetenskappe 48/1. 2008. 51.

${ }^{56}$ Van Rensburg op. cit., p. 264; Behrens is also of the opinion that the OB's actions have held several troops in South Africa, in such a way that hampered Smuts's war effort. OBA, Tape recordings, interview transcript, tape number 57-57A, 1985, JFJ van Rensburg/ KJH Behrens/HM Robinson/HM van der Westhuysen/HJR Anderson, 29.

${ }^{57}$ OBA, Tape recordings, interview transcript, tape number 137, 1977: LM Fourie/S Boshoff, 2. Translated from Afrikaans.

${ }^{58}$ Van Rensburg op. cit., p. 264.

${ }^{59}$ Ibid.

${ }^{60}$ Fourie op. cit., p. 67. Not only did the sabotage actions require more people in South Africa to prevent resistance, but through selective sabotage of trains and railroads, the transport of troops to port cities was also impeded.

${ }^{61}$ A Hagemann. "Very special relations: The 'Third Reich' and the Union of South Africa, 19331939". South African Historical Journal 27/1. 1992. 141-142.

${ }^{62}$ OBA, HM Robinson collection, 4/19, “Die Ossewa-Brandwag-uitstalling: 'n Perspektief". Unpublished pamphlet, PU for CHE, 1988, p. 5. Translated from Afrikaans.

${ }^{63}$ FL Monama. "Civil defence and protective services in South Africa during World War Two, 1939-1945”. Historia 64/2. 2019. 100-101.

${ }^{64}$ Ibid., p. 91.

${ }^{65}$ Van Rensburg op. cit., p. 264.

${ }^{66} \mathrm{Ibid} .$, p. 264.

${ }^{67}$ Ibid., pp. 264-265. With "new danger", Van Rensburg refers to black nationalism and communism.

${ }^{68}$ Blignaut, "Volksmoeders in die kollig ..." op. cit., p. 211.

${ }^{69}$ HO Terblanche. John Vorster - OB-generaal en Afrikanervegter. Roodepoort: CUM Boeke, 1983, 99. Translated from Afrikaans.

${ }^{70} \mathrm{Ibid}$., p. 93. Translated from Afrikaans.

${ }^{71}$ EB Dawson. "Why the delay in dealing with the Ossewa?" Sunday Express. 1 November 1940.

${ }^{72}$ Die Transvaler. "Soldate veroorsaak moeilikheid". 1 February 1941; Visser op. cit., pp. 35-37; For Van Rensburg's view and interpretation of the events of 31 January to 1 February 1941, see Van Rensburg op. cit., pp. 177-183. 
${ }^{73}$ Die Transvaler. "Die Burger val Genl. Smuts skerp aan". 3 February 1941; Visser op. cit., pp. $35-37$.

${ }^{74}$ Visser op. cit., p. 38.

${ }^{75}$ Ibid., p. 39.

${ }^{76}$ Blake op. cit., p. 47.

${ }^{77}$ Visser op. cit., p. 40.

${ }^{78}$ Ibid., p. 40.

${ }^{79}$ Ibid., p. 40.

${ }^{80}$ See for example Die Transvaler. "Soldate veroorsaak moeilikheid" op. cit.; Die Transvaler,

"Die Burger val Genl. Smuts skerp aan" op. cit.

${ }^{81}$ Fourie op. cit., p. 14.

${ }^{82}$ Van Rensburg op. cit., p. 148.

${ }^{83} \mathrm{H}$ Giliomee. "The growth of Afrikaner identity". In H Adam \& H Giliomee (eds), The rise and crisis of Afrikaner power. Cape Town: David Phillip, 1979, 114.

${ }^{84}$ Geyser \& Pruis op. cit., p. 47.

${ }^{85}$ Pasemann op. cit., p. 113. Translated from German.

${ }^{86}$ Geyser op. cit., p. 161.

${ }^{87}$ Ibid., pp. xxix, 95.

${ }^{88}$ Lentin op. cit., p. 139. For more information on Smuts's friendship with Churchill, see Ibid., pp. 138-142.

${ }^{89}$ Anon. "General Smuts on the War". Journal of the Royal African Society 42/167. 1943. 59.

${ }^{90} \mathrm{Nel}$ op. cit., p. 1.

${ }^{91}$ OBA, JP de Villiers collection, 1/2, file 7: Die Vaderland, cartoon, "Die Nuwe Bedeling". Translation of Afrikaans text in cartoon: "And now ladies and gentlemen we end the Afrikaans program and broadcast a statement by General Smuts!"

${ }^{92}$ D O'Meara. Volkskapitalisme: Class, capital and ideology in the development of Afrikaner Nationalism, 1934-1948. Cambridge: Cambridge University Press, 1983, 121.

${ }^{93}$ FS Crafford. Jan Smuts: 'n Biografie. Cape Town: Edina Works, 1947, 350.

${ }^{94}$ Monama, "Wartime propaganda ..." op. cit., p. 105.

${ }^{95}$ O'Meara op. cit., p. 128.

${ }^{96}$ Van der Walt op. cit., pp. 42-43.

${ }^{97}$ OBA, Grootraad collection, 1/4, file 37: Staatsbeleid, oorlog en noodregulasies.

${ }^{98}$ Fokkens op. cit., p. 127.

${ }^{99}$ Van der Walt op. cit., p. 43.

${ }^{100} \mathrm{Ibid}$. Translated from Afrikaans.

${ }^{101}$ OBA, HM Robinson collection op. cit., p. 7; Blake op. cit., p. 55.

${ }^{102}$ Hancock op. cit., p. 338; Van der Walt op. cit., p. 18; Blake op. cit., p. 59.

${ }^{103}$ OBA, HM Robinson collection op. cit., p. 8; Blake op. cit., pp. 55-56.

${ }^{104}$ OBA, Grootraad collection op. cit.; see also Fokkens op. cit., p. 127.

${ }^{105}$ Liebenberg op. cit., p. 382; Terblanche op. cit., p. 99; Marx, "The Ossewabrandwag as a mass movement ..." op. cit., p. 201; C. Marx, "Dear listeners ..." op. cit., p. 159; Blake op. cit., p. 59.

${ }^{106}$ Blake op. cit., p. 59.

${ }^{107}$ OBA, Kommandant-Generaal collection, 2/4 file 19: Correspondence. Order no. 5/1941, 5 March 1941; Die Oosterlig. "Regering sal skroef stywer aandraai". 10 February 1941; Rand Daily Mail. "You can't $\quad$ serve two masters". 19 February 1941; Die Volksblad. "Belet om lede te wees van Ossewa-Brandwag". 1 March 1941; Die Suiderstem. "Ossewa-Brandwag in ban gedoen". 1 March 1941; Sunday Express. "OB ban affects thousands of state employees". 2 March 1941; Fokkens op. cit., p. 128; Marx, "The Ossewabrandwag as a mass movement ..." op. cit., p. 216; D Prinsloo. "Dr. H.F. Verwoerd en die Ossewa-Brandwag, 1938-1952". Kleio XVII/1. 1985. 73-85. The theme is also briefly touched upon by Venter op. cit., p. 75. 
${ }^{108}$ OBA, Kommandant-Generaal collection, 2/4, file 19, 5 March 1941 op. cit. Translated from Afrikaans.

${ }^{109}$ Ibid.; Die Vaderland. "Minister Lawrence kry wye magte". 4 February 1941. Translated from Afrikaans.

${ }^{110}$ A van Lingen. "Ossewa cannot be banned in Civil Service". Sunday Times. 1 December 1940; Die Volksblad. "Polisie belet om lid te word van Ossewa-Brandwag". 23 November 1940.

${ }^{111}$ Blake op. cit., p. 60. Translated from Afrikaans.

${ }^{112}$ OBA, Kommandant-Generaal collection, 2/4, file 19, 5 March 1941 op. cit. Translated from Afrikaans.

${ }^{113}$ Ibid. Translated from Afrikaans.

${ }^{114}$ Visser op. cit., p. 104.

${ }^{115}$ For existing research on the Stormjaers, see Visser op. cit., p. 104; Fokkens op. cit., pp. 130132; Marx, Oxwagon Sentinel ... op. cit., pp. 353-362; JJ Badenhorst. "Die organisasiestruktuur van die Ossewa-Brandwag”. MA thesis. PU for CHE, 1985, 59.

${ }^{116}$ OBA, Tape recordings, interview transcript, tape numbers 3-5 \& 120, 1973: HC van Rooy/ HM Robinson/LM Fourie/JS Coetzer/AS Spies, p. 69.

${ }^{117}$ Visser op cit., pp. 104-105.

${ }^{118}$ Ibid., p. 105.

${ }^{119}$ Ibid., p. 123.

${ }^{120}$ JJ Badenhorst. "Vroeë organisasiestruktuur van die Ossewa-Brandwag". Joernaal vir Eietydse Geskiedenis 12/3. 1987. 63.

${ }^{121}$ Blake op. cit., p. 67.

122 Ibid., p. 67.

${ }^{123}$ Van Rensburg op. cit., p. 263.

${ }^{124}$ OBA, HM Robinson collection op. cit., p. 5. Translated from Afrikaans.

${ }^{125}$ For more information on Robey Leibbrandt see A Blake. Robey Leibbrandt: ' $n$ Lewe van fanatisme. Johannesburg: Jonathan Ball, 2019.

${ }^{126}$ Blake, Wit Terroriste ... op. cit., p. 227.

${ }^{127}$ OBA, Kommandant-Generaal collection, 1/2: Miscellaneous, 1 February 1941. Translated from Afrikaans.

${ }^{128}$ OBA, Kommandant-Generaal collection 1/2: Miscellaneous, 5 February 1940. Translated from Afrikaans.

${ }^{129}$ Blignaut, "Volksmoeders in die kollig ..." op. cit., p. 211.

${ }^{130}$ OBA, Kommandant-Generaal collection, 1/2: Miscellaneous, 5 February 1940.

${ }^{131}$ Die Burger. "1,600 mense in kampe". 17 June 1940.

${ }_{132}$ Die Volksblad. "Internering deur regering verskerp". 12 November 1940.

${ }^{133}$ Fourie op. cit., p. 3.

${ }^{134} \mathrm{Nel}$ op. cit., p. 55. Translated from Afrikaans.

${ }^{135}$ Van Rensburg op. cit., p. 149.

${ }^{136} \mathrm{Nel}$ op. cit., p. 50.

${ }^{137} \mathrm{C}$ Blignaut. "From fund-raising to Freedom Day: The nature of women's general activities in the Ossewa-Brandwag, 1939-1943". New Contree 66. 2013. 126; Blignaut, "Volksmoeders in die kollig ..." op. cit., p. 169.

${ }^{138}$ For more information on the Distress Relief Fund, see C Blignaut. “'Skep julle kommando's in reddingslaers om! Een vir almal, almal vir elkeen!': Die Ossewa-Brandwag se maatskaplike beleid van Sosiale Volksorg, 1943-1952”. New Contree 74. 2015. 72-89.

${ }^{139}$ OBA, Tape recordings, interview transcript, tape number 157, 1978: LM Fourie/KJH Behrens, p. 8.

${ }^{140}$ Blignaut, "Volksmoeders in die kollig ..." op. cit., p. 208. 
${ }^{141}$ Die Burger. "Smeekstem van vroue". 24 June 1940.

142 OBA, A Potgieter collection, 1/4, "Die oproep van 1940"; see also Blignaut, "Volksmoeders in die kollig ..." op. cit., p. 208.

${ }^{143}$ OBA, A Potgieter collection, 1/4, "Die onderhoud by minister JH Hofmeyr".

${ }^{144}$ For exact figures on the amount of signatures recorded in petitions, and telegrams sent, see

Blignaut, "Volksmoeders in die kollig ..." op. cit., p. 210. Translated from Afrikaans.

${ }^{145}$ Blignaut, "Volksmoeders in die kollig ..." op. cit., p. 210. Translated from Afrikaans.

${ }^{146}$ OBA, Photo collection, record number M2529.

${ }^{147}$ OBA, Kommandant-Generaal collection, 1/2: Miscellaneous, 9 February 1940.

${ }_{148}$ OBA, Kommandant-Generaal collection, 1/2: Miscellaneous, 13 February 1940.

${ }^{149}$ FL Monama. "The Second World War and South African society, 1939-1945". In T Potgieter \& I Liebenberg (eds), Reflections on war: Preparedness and consequences. Stellenbosch: Sun Press, 2012, 50.

${ }^{150} \mathrm{~K}$ Fedorowich. "German espionage and British counter-intelligence in South Africa and Mozambique, 1939-1944". The Historical Journal 48/1. 2005. 209-216.

${ }^{151}$ OBA, Kommandant-Generaal collection, 2/4, file 19: Correspondence, 27 January 1941. Translated from Afrikaans.

152 Ibid.

${ }^{153}$ Ibid.

${ }^{154}$ OBA, Kommandant-Generaal collection, 2/4, file 19: Correspondence, Ossewabrandwag Kaapland Order no. 36/41, 10 September 1941.

${ }^{155}$ OBA, Kommandant-Generaal collection, 2/4, file 19: Correspondence, 8 September 1941.

${ }^{156}$ OBA, Kommandant-Generaal collection, 2/4, file 19: Correspondence, 24 November 1941.

${ }^{157}$ OBA, KJH Behrens collection, 2/11: Meetings and reports, minutes of the Grootraad meeting held on 11 and 12 March 1943, pp. 5-6.

${ }^{158}$ OBA, Pamphlet collection, 2, “OB-uitgawes nommer 3 van 1943: Die Ossewa-Brandwag en die parlementsverkiesing, die soldate en die kommunisme", p. 3.

${ }^{159}$ OBA, OB-maatskappye collection, 11/8/52: "Die Kroon teen PP du Plessis en 51 ander hofverslae"; also see HM Robinson collection op. cit., p. 6.

${ }^{160}$ For an in-depth discussion on Visser and Van Blerk, as well as the bombing of the Benoni Post Office, see Blake, Wit terroriste ... op. cit., pp. 106-116.

${ }^{161}$ Fourie op. cit., p. 82.

${ }^{162}$ OBA, OB-koerante collection, Die OB, 5 August 1942, pp. 5-6; and Die OB, 12 August 1942, p. 4.

${ }^{163}$ Fourie op. cit., p. 83.

${ }^{164}$ Blake, Robey Leibbrandt ... op. cit., pp. 24-50.

${ }^{165}$ OBA, OB-maatskappye collection, 11/8/53 to 11/8/63: "Die Kroon teen Robey Leibbrandt hofverslae" vol. 1-11. For more information on Leibbrandt, see Blake, Robey Leibbrandt ... op. cit., p. 2019 and Strydom op. cit.

${ }^{166}$ Blake, Robey Leibbrandt ... op. cit., pp. 200-203.

${ }^{167}$ For more information on the Afrikaner Broederbond and its role in the rise of Afrikaner nationalism, see D O'Meara. "The Afrikaner Broederbond 1927-1948: Class vanguard of Afrikaner nationalism”. Journal of Southern African Studies 3/2. 1977. $156-186$.

${ }^{168}$ OBA, OB-koerante collection, Die OB, 16 June 1948, p. 3.

${ }^{169}$ Visser op. cit., p. 196; OBA, HM Robinson collection op. cit., p. 9; Prinsloo op. cit., p. 85.

${ }^{170}$ Geyser \& Pruis op. cit., p. 48.

${ }^{171} \mathrm{Nel}$ op. cit., p. 57.

${ }^{172}$ Visser op. cit., p. 142.

${ }^{173}$ OBA, Grootraad collection, 1/2/12: Agendas en notules. Minutes of the OB Grootraad meeting, 1 October 1942. 
${ }^{174}$ Fourie op. cit., p. 44.

${ }^{175}$ Smuts papers, 88, 304, Letter from JFJ van Rensburg to Jan Smuts, found in J van der Poel, Selections from the Smuts papers, vol. VII, 205.

${ }^{176} \mathrm{OBA}$, Grootraad collection, 1/3/21: Uitvoerende Raad agendas en notules. Minutes of the meeting held on 10 July 1948. 